\title{
Raising Legal Awareness for Out-of-School Children in Kampung Paropo through Non-Formal Legal Education
}

Eka Merdekawati Djafar, Kevin Tappangan, Andi Nurul Azizah, Syawirah M, Riska Apriana, Ayu Lestari Indah

Faculty of Law, Hasanuddin University, Indonesia

DOI: $\underline{10.36348 / \text { sijlcj.2020.v03i11.010 }}$

| Received: 05.10.2020 | Accepted: 17.11.2020 | Published: 19.11.2020

*Corresponding author: Eka Merdekawati Djafar

Abstract

With regard to the right to an education for each citizen as regulated in the article 31 section (1) of the 1945 Constitution of the Republic of Indonesia, it is the state responsibility to provide educational access for the citizen. Education is the accurate facility for improving the quality of human resources and promoting appropriate and critical mindset in addressing the issues within the local, national and transnational life. $20 \%$ of National Budgetary Plan is allocated to educational sector. However, this effort is still unable to solve the Indonesian educational issues. This study employed a qualitative method. The data were collected through in-depth structured interview, legal education program and documentation. The collected data were analyzed with descriptive qualitative analysis. The results showed that there were several influencing factors promoting the large number of out-of-school children in Kampung Paropo, Makassar including low financial capacity and lack of parental care which consequently, contributed to the increasing criminality such as violent robbery, thievery, and drug abuse among the out-of-school children. Therefore, it is necessary to provide accurate effort in anticipating the increasing criminality among the out-of-school children and in encouraging their legal awareness. Non-formal legal education was to be an accurate strategy in raising legal awareness and in instilling moral values among the out-of-school children in Kampung Paropo, Makassar.

Keywords: Legal awareness raising, legal education, out-of-school children, non-formal education.

Copyright (C) 2020 The Author(s): This is an open-access article distributed under the terms of the Creative Commons Attribution 4.0 International License (CC BY-NC 4.0) which permits unrestricted use, distribution, and reproduction in any medium for non-commercial use provided the original author and source are credited.

\section{INTRODUCTION}

Awareness can be defined as a commitment to be effectively involved in achieving a goal towards the implication of consciousness. This awareness should be confirmed that it is not restricted to the cognitive aspect and without any goal. It is further related to the reality of attitude within social life. Formally and physically, this attitude is reflected in the legal constitution.

In forming an implication, law and legal awareness are intercorrelated. According to Lemaire [1], legal awareness is a factor in the law foundation. Krabbe also confirmed that legal awareness is the source of all laws [2].

This legal awareness is the awareness to act according to the rule of law. The legal awareness of society seems like a bridge that connects the rule of law with the member of society. L. M. Friedman tends to define it as "law culture" or the values and attitudes that contribute to the implementation of law. After the establishment of legal awareness, the legal complience of relevant rules will be reflected in society.

One alternative solution to raise legal awareness is to provide either formal or non-formal legal education. Education is undoubtedly a very essential sector in affecting the quality of a nation. The failure and success in educational factor will automatically affect the national welfare. Indonesia as a welfare state guaranteed the accessibility of proper education to Indonesian citizens as regulated in fourth paragraph in the preamble to the 1945 Constitution of Republic of Indonesia: (1) to protect the whole people of Indonesia and the entire homeland of Indonesia; (2) to advance general prosperity; (3) to develop the nation's intellectual life; (4) to contribute to the implementation of a world order based on freedom; (5) lasting peace and social justice.

However, the inequality of Indonesian educational development seemed to be very apparent in a number of regions resulting in the unequal quality of education in one region over other regions. The 
inability to access education may be caused by the economic factor. Indifference to the importance of education may also be one cause that contributes to this crucial issue. Furthermore, low quality of education may also contribute to the increase of criminality among the out-of-school children because they lacked of moral guidance and good character development where these two can dominantly be learnt from formal education. Formal education may help to shape their positive attitude and minimize the criminality emerging from the children.

Makassar city is a metropolitan city with the advanced economic sector and development. However, it cannot be denied that the government still cannot completely provide optimal educational access. This increased the number of out-of-school children and this phenomenon was very apparent in Kampung Paropo.

Kampung Paropo is a small urban village located in Panakukang Sub-District with high educational backwardness. This educational backwardness can be observed from the high number of out-of-school children which consequently, contributes to the lack of legal awareness within the area. It is undeniable that the criminality rate in Kampung Paropo is also high and it is proved by the notorious local label of Texas Area for Kampung Paropo.

Such circumstance is truly contradicted with the constitution goal of Republic of Indonesia and therefore, solutive effort is necessary to solve this issue.

\section{RESEARCH METHOD}

This study employed qualitative method that attempted to comprehend and to describe a phenomena that were experienced by the subjects of the study such as attitude, perception, motivation, and behavior holistically and descriptively in the form of description in natural particular context by applying various natural methods [3]. This research was performed in Kampung Paropo, Makassar since the research site reflected the characteristics of low quality of educational development and low level of legal awareness, and high intensity of criminality among the out-of-school children. 3 months were spent on completing research preparation, data collection and writing the results.

The data were collected through in-depth interview [4]. In order to ensure the interview focusing on the research problem, structured interview model developed by Basuki [5] was employed. Structured interview can be defined as an interview using a list of prepared questions. The target information collected during the interview included the number of out-ofschool children, common criminal cases occurred in the corresponding area, the community's effort in minimizing the criminality emerging from the out-ofschool children.
Legal Education Program was also carried out as research team's efforts in collecting information related to the number of out-of-school children, measuring legal awareness in children concerning the legal awareness urgency, and providing non-formal legal education that was easily comprehended by the children. Documentation was also carried out in order to document and store both important digital objects and physical objects during the research. The collected data were analyzed with qualitative analysis and logical selection was also implemented in order to avoid mistakes during the data analysis. The results were interpreted descriptively through elaboration, description and explanation of the research problems.

\section{RESULTS AND DISCUSSION}

Law is the product of a culture as the blueprint of behavior that provides guidelines of normative values. Therefore, culture encompasses a system of objectives and values. Criminal acts performed by outof-school children could affect the social relationship of school-age children. Therefore, the existence of out-ofschool children may threaten society. This sometimes leads to discriminative responses to the out-of-school children due to the negative stereotypes labelled by society. Discriminative responses from society may vary. Some may prevent their children to interact with the out-of-school children due to negative stereotypes. They are sometimes labelled as the children with no bright future and social parasite to the other school-age children. This paradigm is deeply and continuously rooted within the society as a common perspective among society.

All of human beings are in need of different needs. In order to fulfill their needs, they are a possibility to perpetrate violated acts.

- Ignorance of the law;

In fact, there is no human being not knowing the law that governs society. In any society, there will be a system of law. Particularly in Indonesia, it may be very disappointing since there was a number of regulations legalized by the government but some of the hierarchy elements in the society were not familiar with them. Lack of socialization and lack of interest may be the causes of this. For example, majority of the people tend to not understand the regulation on pornography and the consequences or the sanctions of it.

- Violating the law due to political or material power;

Some people with greater political and material power may consider themselves invulnerable to applied normative values although according to the constitution, all persons shall be equal before the law. However, in reality, there are elites with great political and material power as well as popularity that may affect the legal procedure on their 
normative violation. Their cases will likely be easily closed and they easily evade heavy punishment.

- Deliberate intent to violate the law (Dolus); Dolus is a deliberate intent to violate a law such as the article 338 in the criminal code concerning crimes against life, the article 245 in the criminal code concerning the falsified currency.

The society, in general understands that criminal murder is a violation against the law. However, not a few people still commit to violate the law only to fulfill their emotional satisfaction without considering its destructive impacts individually or socially. It is similar to the falsified currency.

There are several contributing factors to the emergence of legal awareness in society:

1. Compliance can be defined as the obedience based on the expectation for a reward and the effort to prevent legal violation. This obedience is not based on one belief of the related purpose of rule of law, and dominantly based on the authority supervision. As the consequence, this compliance will be present if there is a strict law supervision to the implementation of rule of law.

2. Identification may be present if the compliance of rule of law is also present not because of its intrinsic value, but to maintain the authorized group membership in implementing the rule of law. The attractiveness of compliance is the advantage acquired from the relationships and therefore, the compliance depends on the good or bad of the interaction.

3. Internalization. in this stage, a person obeys rules of law due to the intrinsics of the reward from the compliance. The substance of rules of law is in accordance with the values related to the person or due to the transformation in the previously adopted values. The result of this process is conformity based on intrinsic motivation. The central point from the strength of this process is the personal belief towards the purposes of related rules of law apart from the influences or values to the group, authorities or its supervision.

Steps to solve the decreasing legal awareness within the society should be taken and it is necessary to analyze its causes. The decrease in legal awareness is a symptom of social change. One cause of social change according to Arnold M Rose as cited from Soekanto[6], is the contact or conflicting cultures. The great wave of tourism in Indonesia also tends to stimulate social changes. The foreign movies, television, magazine or other media information with harmful content or with the content that violates the law will also contribute to the decrease in legal awareness among the society.
According to Soerjono Soekanto, the indicators of legal awareness are, in fact, the concrete guidelines for legal awareness level. These indicators are as follows:

1. Legal Literacy

Legal literacy can be defined as a circumstance where a person can identify that certain act or behavior are regulated within the law. The rule of law in this context is the written law or the unwritten law whether a certain act or behavior is allowed or prohibited before the law.

2. Legal Understanding

Legal Understanding can be defined as a circumstance where a person has the knowledge and comprehension of the certain law. For example, the accurate understanding among the society regarding 17 points of the importance in Law no. 20 of 2003 concerning the Indonesian Educational System.

3. Legal Attitude

Legal Attitude can be defined as a circumstance where a person tends to perform certain evaluation on certain law.

4. Legal Behavior

Legal Behavior can be a person or in a society of its citizens obeys applicable regulation.

All of the four indicators showed different levels of certain legal awareness in its manifestation. If a person understands the law, it can be identified that his or her legal awareness is still on the low level. However, if a person or a community behaves according to legal behavior, their legal awareness level is high. Before conducting this 3-month research, it can be understood that a great commitment was required to achieve optimal results concerning non-formal legal education. The results of the interview with the participants, their parents and surrounding society showed that this program included creative and beneficial activity for out-of-school children in instilling moral values and legal education to minimize the criminal acts emerging from them.

The partnering team in this study also commented that there were significant positive changes on the children' behavior upon participating in this program such as their increasing tendency to regular pray, good legal awareness, and giving good advice to their friends who perform any misconduct. In addition, the results of the pre and post-test also as well as data analysis indicated the effectiveness of the program.

Before the implementation of legal education program, the out-of-school children were identified to have performed criminal acts such as thievery, violent robbery, and drug abuse. Therefore, after the identification of such causes of decreasing legal awareness, proper legal education may be considered as an effective and efficient step in educating and guiding 
the society including the children to raise their legal awareness [7].

Through formal and non-formal legal education Education is not an "einmalig' or incidental activity, but it is a continuous and intensive activity especially in terms of legal awareness education. This activity will require extensive progress. Therefore, it is not exaggerating to say that the satisfying result of intensive and continuous educational program in legal education can be identified after at least 18 or 19 years [8].

Some important aspects imposed within the legal education are as follows: (1) the legal awareness imposition on how to be a good Indonesian citizen and the rights and obligations of Indonesian citizens. Every citizen should understand the relevant constitution in their country. (2) The imposition of the legal organization, implementation and enforcement as well as protection. (3) Further imposition on the prohibition of legal violation within the social life and the obligation to obey legal obligations as well as the efforts in the legal education and implementation. (4) The imposition of the prohibition in harming others and careful behavior. (5) More comprehensive imposition on the rights and obligations as Indonesian citizens, national structure, Pancasila and the Constitution, and the important articles within the criminal code (6) The understanding for legal aid access (7) The implementation of school rules that should be obliged, (8) Every violater should be punished through the supervision of the teachers that will adjudicate the violaters of school rules.

Reinforcing the Indonesian Minister of Law and Human Rights regulation no. M.01.PR.08.10 of 2006 concerning the legal education pattern amended as Indonesian Minister of Law and Human Rights regulation no. M.01.PR.08.10 in 2007. The regulation of national law development agency no. 03.05.73 of 2008 concerning the establishment of legal literacy among the families and the village.

For example: (1) Improving the campaign on legal awareness in the context of formal education. (2) Developing the weekly program for raising legal awareness (3) Developing creative activities such as competitions, writing, motto creation related to legal awareness. (4) Giving appreciation for the people who obeyed the constitution. (5) Improving legal education through talks, discussion, dialogue, simulation and so on. (6) Developing legal education through radio, television, video, magazine, newspaper, and so on. (7)Improving legal education through various reading sources such as comic or strips with heroic story. (8) Improving the campaign of legal awareness through books, brochure, leaflets, films, slide, VCD and other interesting visual media.
1. Establishing public services by professional, consistent, accountable, just and transparent legal structure.

2. Establishing coordinating networking for interinstances of the governmental and private sector specializing in legal education program.

3. Establishing the rule of law in accordance with the existing law within society.

4. Improving the performance of consistent and objective law reinforcer.

5. Improving legal awareness within society through the elite's participation.

6. In addition to legal education through non-formal education for out-of-school children, there should be available program for legal education in the schools in the villages or the cities from elementary, junior and senior high school level. The legal education material should employ similar module according to the level of education.

7. The legal education material in the elementary level focuses on the first indicator of basic legal awareness. Although in this study, legal education was focused on out-of-school children, it is also expected that the elementary school students could understand certain behavior regulated in both written and unwritten legal system. The behavior is related to both permitted or prohibited by law.

8. The legal education material in junior high school level should focus on the indicator of legal understanding. The aim of legal understanding is to provide knowledge for out-of-school children concerning certain regulations. For example, the proper legal understanding of the society related to Law no. 20 of 2003 concerning the Indonesian Educational System.

9. The material of legal education for out-of-school children focuses on the indicators of legal attitude and behavior. In this context, out-of-school children are expected to conduct evaluation on certain law and behave according to the law or to obey the relevant rules.

On the other hand, this may not only be applied to formal education but also may be applied to non-formal education. For example, the implementation of legal education was provided as a non-formal legal education where the out-of-school children were encouraged to positive missions such as helping people around them, becoming more passionate in gaining money inappropriate ways and avoiding criminal acts because they had already understood the consequences of violating the law.

The element of the society as the target of this program was the out-of-school children in Kampung Paropo. According to our research, they mostly spent their day working as parking officer, beggar and odd laborer including grave digger and grave cleaner. Some of them also worked as the shop or restaurant security. Based on the data and the information collected during 
this study, it can be concluded that there were several reasons why they became out-of-school children including broken home, lack of parental care, environmental influences, the parent's mindset and economic condition. The emerging out-of-school children among the society could disturb the public based on the explanation pointed out by the research team partner. The local community expected that the non-formal legal education program could promote legal awareness in the out-of-school children and could minimize criminal acts from them. As for the effect of lacking moral value and legal education, the majority of out-of-school children cannot understand the consequences of their negative acts and therefore, the criminal acts emerging from them tend to increase.

The activity provided in this study aimed to provide legal understanding of the consequences of violating the law, to guide and educate the children and to reset the psychological and spiritual behavior of the children. Through this program, the out-of-school children were expected to have good personality for the people around them. The research team also attempted to explore their inner potential to help them busy with positive activity while it will avoid them from negative acts.

\section{CONCLUSION}

Non-formal legal education in Kampung Paropo served as a persuasive effort to provide moral understanding and legal literacy for the out-of-school children. Within its program, the children were involved in a creative and interesting learning activity with the expectation that this activity will consistently enable the children to explore benefit knowledge. The emergence of out-of-school children was caused by numerous factors and it is not because of their wishes. Those factors were broken home family, negative peer group, low economic background and some other factors. The out-of-school children were basically the children with lack of parental care and affection and therefore, accurate steps in responding to the phenomena of out-of-school children were necessary. One of the accurate steps that can be taken is the methods employed in the program designed in this study. The method in this study employed persuasive approach such as educating them in relaxing and creative ways. Through this approach, the children will assess that the legal education program was not something burdening for them. In addition, assistance system by developing chemistry in out-of-school children was also very important. In this context, the assistance and the children will develop positive emotional bonding.

\section{REFERENCES}

1. Lemaire, W. L. G. (1952). Het Recht in Indonesia, W. Van Hoeven, Gravenhage.

2. Apeldoorn, L. J. V. (2001). Pengantar Ilmu Hukum, Jakarta: PT. Pradnya Paramita, p. 9.

3. Moleong, J. L. (2012). Metodologi Penelitian Kualitatif, $1^{\text {st }}$ ed, Remaja Karya, 6.

4. Kadarudin. (2020). Mengenal Riset dalam Bidang Ilmu Hukum: Tipologi, Metodologi, dan Kerangka, Ponorogo: Uwais Inspirasi Indonesia, p. 171.

5. Basuki, S. (2010). Metode Penelitian, Jakarta: Penaku, p. 171.

6. Soekanto, S. (1975). Sosiologi: Suatu Pengantar, Jakarta: PT. Raja Grafindo Persada, p. 35.

7. Sudikno, M. (2005). Mengenal Hukum: Suatu Pengantar, Bandung: Liberty.

8. Ibid. 